\title{
SKILLS AND COMPETENCIES REQUIRED BY A FORENSIC ACCOUNTANT: ANEXPLORATORY STUDY CONDUCTED IN SRI LANKA
}

\author{
K.H.Perera ${ }^{1}$ J.K. Undugoda ${ }^{2}$ \\ University of Kelaniya ${ }^{1}$, Ernst \& Young ${ }^{2}$
}

\begin{abstract}
The 2016 Global Fraud Survey steered by the Association of Certified Fraud Examiners (ACFE) illustrates that the organisations established worldwide lose approximately 5\% of their annual revenue due to fraud. With the increase in fraudulent accounting practices all around the world, the need for forensic accountants has increased to look for indicators of suspicious financial activities and fraudulent activities. Regulators continue to increase the responsibility for auditors to detect fraudulent financial statements, however, there is a mismatch between the supply of and demand for auditors with forensic accounting skills. The main objective of the study is to determine whether forensic accountant needs any special skills and competencies in their profession as forensic accountants and to identify the same. The study is conducted based on a sample of professionally qualified accountants in forensic practice and auditing. Data was collected through questionnaire and analysed using Statistical Package of Social Studies (SPSS). The research identified that fraud risk assessment, deductive analysis and diagnostic skills as the highest ranked skills, whereas, the least ranked skill was marketing. It is suggested that the use of forensic accounting procedures or services to detect financial reporting frauds and corruption practices should be increased in organisations by having or recruiting more forensic accountants with required skills and competencies.
\end{abstract}

Keywords : Forensic accountant, skills, frauds, financial statements

\section{Introduction}

Frauds have been encountered over many generations, however in the past two decades many prominent financial scandals have been witnessed globally, such as Enron, WorldCom and Satyam scandals (Carozza, 2002; Melancon, 2002; Pearson and Singleton, 2008). Further, in the context of Sri Lanka, being a Lower Middle-Income country, Golden Key, Pramuka Bank, ceylinco group, ETI Finance and bond scam were the prominent corporate scandals. Tunca and Crowther (2006) argue that even if an accountant behaves ethically, he/she should know how to behave when faced with a fraud in the business environment and so needs knowledge about fraud detection, fraud prevention, fraud investigation and fraud reporting. This is where forensic accounting education is required for an entity.

Bhasin (2013) defines the term 'fraud' as 'using deception to dishonestly make a 
personal gain for oneself and/or create a loss for another'. Albrecht, Albrecht and Albrecht, (2008) argued that fraud is rarely seen and the symptoms of fraud are usually observed, where such symptoms do not necessarily mean fraud is being undergone as it may be caused by mistakes. But the act might also be deliberate. According to Rezaee (2005), financial statement fraud is a deliberate attempt by corporations to deceive or mislead users of published financial statements, especially investors and creditors, by preparing and disseminating materially misstated financial statements. Rezaee, Daniel, Michael and Suen (2016) pointed out that the focus on financial reporting fraud (FRF) redirected towards prevention and detection particularly during the period between 2007 and 2009, when the global financial crisis was in existence. Fraud remains a significant problem in both local and global context even after many efforts over investigations as there appears to be new forms of frauds day by day (Prabowo, 2014).

The common view of the various stakeholders is that, a public practice accountant will assume an active role in providing reasonable assurance not only in financial reporting, but also regarding responsible corporate governance, detecting and preventing fraudulent financial activities (Fullerton and Durtschi, 2004; Rezaee \& Burton, 1997). Rokosu (2015) argues that there is an expedition for auditors to enhance their skills with regard to fraud detection, prevention and control. According to the study conducted by Okoye and Akenbor (2009), forensic accounting stemmed from the traditional accounting and finance disciplines given the recent financial scandals requiring more professionalism. It further states that the forensic accounting is not purely a new field whereas it has been in existence a long-time back in history though it was not separately designated as forensic accounting during that time (Okoye \& Akenbor, 2009; Grippo and Ibex, 2003; Crumbly, 2001).

No written documents have been published until 1946 with regard to forensic accounting though it has been in existence for many decades and centuries. In 1946, Maurice E. Peloubet, a partner in a New York accounting firm first published an article titled as "Forensic Accounting: Its Place in Today's Economy" (Okoye \& Akenbor, 2009; Akhidime \& Uagbale-Ekatah, 2014). Forensic accounting is often equated with fraud examination or fraud auditing (DiGabriele \& Huber, 2013). However, forensic accounting is a challenging multidisciplinary field that substantially interacts with auditing, economics, finance, information systems, law, psychology, sociology, and criminology (Smith and Crumbley, 2009; DiGabriele \& Huber, 2013).

Having discussed the importance of forensic accounting in an environment where the number of financial statement frauds are increasing, the demand for forensic accountants is rapidly increasing. Therefore, it is important to identify the existence of any specific skills that are required by a forensic accountant. Hence, the main objective of the research study is to determine the special skills and competencies required in their profession in Sri Lanka. 


\section{Research problem}

According to Thilakarathna (2010), Sri Lanka should establish and develop the forensic and investigative accounting services as soon as possible to reduce unexpected corporate failures. However, still there is high volume of frauds happening in Sri Lanka. This may be due to the facts that adequate measures have not been undertaken or the profession needs to improve the quality of their professionals. Therefore, this study is conducted in order to get the view point of the Accountants in practice. Hence, this research was conducted to find answers for this problem, which is to determine the special skills and competencies required by forensic accountants in engaging in their profession.

Referring to the problem statement stated above, following research question can be established. 'What are the special skills and competencies need for the Forensic Accountant in their profession in Sri Lanka?'

\section{Research gap}

The 2016 Global Fraud Survey steered by the Association of Certified Fraud Examiners (ACFE) illustrates that the organizations established worldwide loose approximately about $5 \%$ of their annual revenue due to fraud. Multiplying the ACFE percentage of loss due to fraud by the gross domestic product of Sri Lanka would mean an annual cost of over US Dollars 4.07 billion (Sri Lankan Rupees 591.95 billion) in Sri Lanka alone. According to Transparency International Sri Lanka (2017), 89th position has been secured by Sri Lanka out of 176 countries in the 2018- Corruption Perception Index.
International Journal of Accounting \& Business Finance Vol.6.No.2 December 2020 Issue. pp. 1 - 18

Forensic accountants play an important role in government where they need to look for signs of suspicious financial and fraudulent activities. The use of forensic accounting procedures or services to detect financial reporting frauds and corruption practices should be increased in the organisations by having or recruiting more skilful forensic accountants.

In Sri Lanka there should be proper forensic accounting education bodies as well as skilful forensic accountants in oder to minimise or eradicate frauds and corruptions. According to Thilakarathna (2010), Sri Lanka should establish and develop the forensic and investigative accounting services as soon as possible to reduce unexpected corporate failures. Even though the value of forensic accounting education is emphasised from the last decade, Sri Lankan state universities are not offering sufficient forensic accounting education in their curriculum.

\section{Practical implications of the study}

Most of the literature on this area are based on the researches conducted in the Western world (Gaither, 2018; Nicolae, 2017; Arežina, 2014; Ahadiat, 2010; Davis, 2010; Akers, 2003; McMullen, 2010; Caliyurt and Crowther, 2006; Brooks and Labelle, 2006; Seda and Kramer, 2014; KrameR, Seda and Bobashev, 2017) and African countries (Ademola, 2017; Kodongo, Mokaleli-Mokoteli and Maina, 2014; Okoye and Akenbor, 2009; Dada, 2016; Arewa, 2018; Kingdom and Aduwo, 2016; Oladejo and Oluwaseun, 2015; Okoye and Jugu, 2010). Being an Asian country and a developing country, the nature and extent of crimes are different from these developed countries. 
Therefore, the research aimed at identifying whether the existence of culture-specific variables would lead to a different set of skills and competencies for the forensic accountants in Sri Lanka compared to the western world.

Having identified the skills and competencies for a forensic accountant in Sri Lanka, certain parties would be benefited in different ways. Since forensic Accounting profession is growing in Sri Lanka, management of entities can decide on recruiting criteria for the new recruits. Accordingly they will be able to attract, develop and retain efficient and effective employees with their entity. Furthermore, professional bodies and university academics that are in the process of introducing forensic accounting qualifications/ degrees could develop the respective curriculums in such a way that will help the students to develop the skills and competencies that are required for a forensic accountant.

Therefore, this research aims at identifying the skills and competencies required by a forensic accountant, from Sri Lankan perspective paying attention to cases that Sri Lanka had to come across in the recent past.

\section{Literature review}

\subsection{Theoretical background}

The stakeholders in corporate manage ment include the shareholders, managers, customers, regulatory

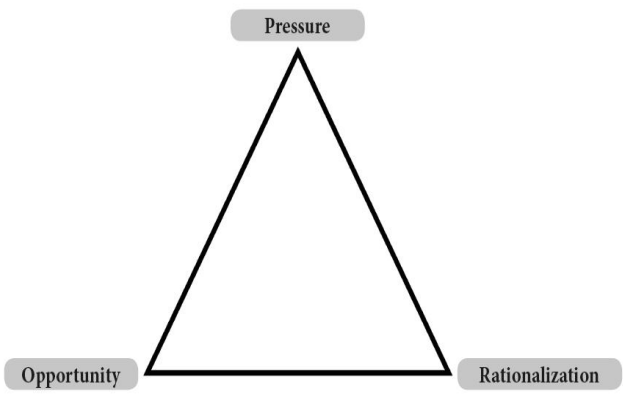

authorities, suppliers and other internal and external parties associated with the business. The management of the corporate is the stakeholder category that would operate business activities for the best interest of the rest of the stakeholders thus majority of fraudulent activities that occur within the corporate that will lead to forensic investigation are due to the responsibility of management. Accordingly, since there is no universally accepted theories for forensic accounting following theories are closely related to fulfilling responsibilities of business towards its stakeholders.

\subsubsection{Fraud tringle}

Cressey (1953) developed a model of fraud triangle figure. The following depicts the model developed by him. The top element of the diagram represents the pressure or motive to commit the fraudulent act while the two elements at the bottom are perceived opportunity and rationalization where pressure is the financial or emotional force stimulating the laymen to committing frauds; rationalization is the mindset of personal justification for the dishonest actions and opportunity is the ability to execute plans to conduct the fraud without getting caught. 
Consistent with Cressey (1953) Wolfe and Hermanson (2004) developed an extended version of fraud triangle adding an additional element "capacity" beside the three elements identified by Cressey's fraud triangle as perceived pressure, perceived opportunity, and rationalization. The argument was Wolfe and Hermanson (2004) believed that although the fraudster may have the pressure, opportunity to commit the fraud and rationalise the ideology of betraying the trust. Yet, he cannot conceal unless he has the capability to do so.

Figure 1: fraud triangle by Cressey (1953)

\subsubsection{Fraud diamond theory}

This is an extension to the fraud triangle discussed above. In addition to addressing incentive, opportunity, and rationalisation, "fraud diamond" also considers an individual's capability: personal traits and abilities that play a major role in whether fraud may actually occur even with the presence of the other three elements.

\subsubsection{Agency theory}

Fraudulent corporate activities occur within firms due to the existence of differences in behaviour and decisions undertaken by employees of a corporate when one party known as principal delegates the corporate work to agents where separation of ownership and control exists among principals and agents. The differences among these two parties in terms of their utility maximization and goals leads to different attitude to work and acceptance of risk thus this agency relationship among two parties leads to a gap in expectation as they work for their own self-interest.
International Journal of Accounting \& Business Finance Vol.6.No.2 December 2020 Issue. pp. 1 - 18

Further supporting the above Jensen and Meckling (1976) reflects that managers will act in their self-interest due to the fact they have more access to information than the principals hence leading to information asymmetry among the principals and managers raising major concerns in the corporate world with regards to agency cost due to lack of transparent behavior thus leading the path for fraudulent corporate activities.

\subsubsection{Stakeholder theory}

Stakeholder theory is a broad theory where corporates seeks to create value for all its interested parties and not merely the shareholders. To ensure that the corporates succeed have a sustainable future ahead the management of the corporate must keep the interests of customers, suppliers, employees, communities and shareholders aligned with the interest of the management such that the corporates head towards the achievement of all its stakeholder expectation.

However, in a corporate as the management has more control over the operational activities, the rest of the stakeholders will mostly rely on the tasks performed by the management thus given a situation where the management do not conduct its duties in a transparent manner it will lead to fraudulent actions with the corporates, thus the other stakeholder of the company including shareholders will be facing the consequences as the corporate engaging fraudulent activities will not be creating value for its stakeholders. 


\subsection{Empirical evidence}

Okoye and Akenbor (2009) established that one of the challenges facing the development of forensic accounting in developing economies, is the fact that most companies, educational institutions and individuals myopically believe that forensic accounting is not different from auditing, hence they give very little or no attention to it. However, the following table depicts the differences between forensic accounting and auditing (Grippo and Ibex, 2003; Mazni and Mohd, 2008).

Table 1. Comparison of Audit Vs Forensic Accounting

\section{Traditional auditing Forensic accounting and accounting}

Traditional Audit and Mandatory

Accounting is compulsory

Forensic Accounting is done in response to a specific event

Auditors should Forensic accountants possess "professional should possess "Invesskepticism tigative mentality" Measures compliance Deals with Financial with reporting stan- investigation dards

Obtain reasonable as- Findings are used as surance that financial evidence in court or to statements are free of resolve disputes material misstatement

An auditor basically A forensic accountant focuses on material may focus more on transactions seemingly immaterial transactions.
International Journal of Accounting \& Business Finance Vol.6.No.2 December 2020 Issue. pp. 1 - 18

Audit is mainly con- The coverage of forencentrated on Financial sic accounting is wider statements and its than audit dealing with related items both financial \& non-financial issues

Different authors have identified various skills as required by a forensic accountant (Torpe, 2009; Albrecht et al. 2008; Ramaswamy, 2005; Harris and Brown, 2000; Hassan \& Morteza, 2012; Grippo and Ibex, 2003; Messmer, 2004; Crumbley and Smith, 2009; Bhasin 2013; Arizona 2014; Okoye and Jugu, 2010) including familiarity with criminal and civil law and understand courtroom procedures and expectations, investigative skills, including theories, methods, and patterns of fraud abuse, in-depth knowledge of financial statements, the ability to critically analyze them, and a thorough understanding of fraud schemes, analytical skills, technology skills, knowledge in accounting, business, law and human behavior, accounting and auditing, taxation, business operations, management, internal controls, interpersonal relationships, and communication.

According to Di gabriele (2010), forensic accountants should possess various combinations of skill and knowledge in accounting, auditing, law, and investigation techniques. These should be accompanied by strong ethical values and soft skills. The study has identified and suggested the relevant skills for forensic accountants based on a nationwide survey from a random sample of 1,500 accounting academics, forensic accounting practitioners and users of forensic accounting services. The relevant skills included deductive 
analysis, critical thinking, unstructured problem solving, investigative flexibility, analytical proficiency, oral communication, written communication, specific legal knowledge and composure. They must be able to interview and elicit information from potentially uncooperative people and possess a strong amount of skepticism.

A similar study was explored by Davis, Farrell and Ogilby (2010) to improve the efficiency of forensic accounting, through the identification of the knowledge and skills that are necessary for this profession using three groups of respondents (attorneys, academics and public accountants) and they identified 'simplifying the presentation of information', 'auditing' and 'written communication skills' as the most important three skills for a forensic accountant.

\section{Sri Lankan context}

Sri Lanka as well as other countries has experienced many reported frauds during the last decade where safeguarding of public interests were breached. Some of the known high profile corporate scandals such as Enron, WorldCom Inc. and Arthur Andersen resulted in significant regulatory responses, making the regulatory environment in which accountants operate, reasonably complex.

The commission to investigate allegations of bribery or corruption was established by the Act No. 19 of 1994 to investigate allegations of bribery or corruption. The Declaration of Assets and Liabilities Law, No. 1 of 1975 will make more demand to forensic accountants in the future. Furthermore, the importance of the forensic accounting in Sri Lankan domain can be justified through the legal environment on which it is backed by Bribery Commission Act, Anticorruption and related Law etc. Financial Crime Investigation Division (FCID) was established on 26th February 2015 with the objectives of investigating major financial crimes, frauds, unsolicited mega projects, major financial crimes against public property, money laundering, terrorist financing and financial transaction, illegal financial transaction, unlawful enrichments, and offences on financial crimes against national security in Sri Lanka. Further, the 19th amendment to the constitution established Independent Audit Commission providing a legal recovery for Financial Investigations.

Given below are some of the examples from Sri Lankan context during the past few years where such incidents had a severe impact on Sri Lankan economy by way of unfavorable exchange rates, loss of public confidence on non-banking financial institutions and loss of confidence of foreign investors.

i. Golden key credit card company Limited

ii. Impact on Ceylinco group of companies

iii. ETI Finance

iv. Bond scam

Accordingly, it is evidenced that the vision of the Sri Lankan government will require more development of accountants in the discipline of forensic accounting.

\section{Research methodology}

Most of the previous studies conducted to identify the skills and competencies that are required by a forensic accountant were of 
qualitative nature.(Nicolae, 2017; Digabriale, 2010; Okoye and Jugu, 2010; Davis, Farrell and Ogilby, 2010; Rathnasiri and Bandara, 2018; Carnes and Gierlasinski, 2001)

However, they have identified the need of a quantitative analysis into this arena in order to identify the most significant skills and competencies that are required by a forensic accountant in conducting their professional activities.

Therefore, this research was based on positivist paradigm where new knowledge could be discovered through objective measures. In order to achieve the research objectives, quantitative research methodology was used.

\subsection{Population and sample}

The target population for this study defined to include the Professional Accountants in Auditing and Forensic services in Sri Lanka. Out of the total population, 50 Professional Accountants were selected as the sample.

\subsection{Sources of data}

The main source of data collection considered in achieving the objectives of this study was a self-administered structured questionnaire which was distributed among the selected sample. Accordingly, the research will be carried out using primary sources of data in relation to the objectives of the study.

With the objective to elicit as much related information as possible from the respondents. Questionnaire was decided upon because of the following reasons after conducting a pilot survey:

a) To Obtain high response rate questionnaires were distributed among the respondents.

b) It requires less time and energy

c) It offers the possibility of anonymity because subjects' names were not required on the completed questionnaires.

d) Less opportunity for bias as they were presented in a consistent manner.

As per the research objectives, to examine the skills and competencies of the forensic accountants in Sri Lanka, views of the professional accountants were obtained through interviews.

\subsection{Questionnaire design and response rate}

Accordingly, with the research objectives and equipped with an extensive literature review, meetings and discussions with the experts were conducted prior to the conceptualization of the possible questionnaire items. This was important because Forensic Accounting is an emerging profession in the global landscape.

The questionnaire was divided into four (03) sections. It included Likert scale measurement, multiple-choice questions and one openended question. It was designed in such a way that only straightforward, concise, brief and short answers were required. Upon trial, the questionnaire could be answered within 10 15 minutes.

Validation of the Questionnaire: The questionnaire designed for the study was subjected to a validation process for face and content validity. Questions were based on information gathered during the literature review to ensure that they were representative of the generally accepted views on Forensic 
International Journal of Accounting \& Business Finance Vol.6.No.2 December 2020 Issue. pp. 1 - 18

Accounting internationally. The questions were formulated in simple language for clarity and ease of understanding. Clear instructions were given to the subjects and the researcher completed the questionnaires for those subjects who could not read.

Among the selected sample, 30 professionals responded resulting in a $60 \%$ response rate. The analysis was done using this data collected.

\subsection{Data analysis strategies}

Data gathered from the questionnaires have been analysed using the Statistical Package for Social Sciences (SPSS) 23.0. Mainly descriptive and inferential statistics have been used in analysing.

In terms of analytical strategies, first, descriptive statistics regarding the variables will be presented to obtain an overall idea of the sample professional accountants in public practice. Then, in terms of achieving the objective of the present study, i.e., assessing the relevant skills the mean rank method is used to identify the top highest and bottom lowest means for the answers provided.

\section{Analysis and findings}

\subsection{Demographic analysis of the sample}

It was noted, $46.7 \%$ of the respondents were aged from 20 to 25 and another $40.0 \%$ of the respondents were aged from 26 to 30 , followed by the $31-40$ age group representing $13.3 \%$ of the respondents. Further, it was observed that $66.7 \%$ of the respondents were males and $33.3 \%$ are females.

Considering the educational background of the respondents, $73.3 \%$ of the respondents International Journal of Accounting \& Business Finance had a basic GCE A/L as their highest academic qualification and has basic degree which represents $26.7 \%$ of the sample whereas $70 \%$ of the respondents were qualified in chartered accountancy (CA), and 10\% ACCA (UK) and 20\% CIMA (UK).

$86 \%$ of the respondents were represented from big three audit firms (KPMG ,PWC,EY,Deloitte) and 13\% were currently employed in the other audit firms. Further, it was observed that $46.7 \%$ of the respondents were audit managers, $53.3 \%$ were audit supervisors.

$53.3 \%$ of the respondents had $1-5$ years of experience in accounting profession, followed by $43.3 \%$ who had 6 to 10 years of experience, $3.3 \%$ had 11 to 15 years of experience. $80.0 \%$ of the respondents had no experience in the forensic accounting profession, followed by $20.0 \%$ who had less than one year of experience in the forensic accounting profession. The above discussion highlights that the sample is heterogeneous and it is having a diverse representation.

\subsection{Skills required by a forensic accountant in Sri Lanka}

In assessing the first objective of the study, i.e. Assessing the relevant skills forensic accounting services, the mean values were calculated (based on the likert scale used for the questionnaire, i.e. 1 - least important and 5 - most important) as shown below;

Table 2 . Skills required by a forensic accountant 


\begin{tabular}{ll}
\hline Skills & Mean \\
\hline Deductive analysis & 4.9333 \\
Fraud Risk Assessment & 4.9333 \\
unstructured problem solving & 4.8667 \\
Diagnostic (individual's ability & 4.7667 \\
to identify a particular problem & \\
and define it) & \\
Composure & 4.6333 \\
Solve structured problems & 4.5000 \\
Critical Thinking & 4.4000 \\
Time management & 4.1000 \\
Think like the wrongdoer & 4.0667 \\
Technical Accounting (the abili- & 4.0333 \\
ty to apply technical knowledge & \\
in accounting & \\
Auditing & \\
Team working & 4.0333 \\
Understand the goals of a case & 4.0333 \\
Communication & 4.0000 \\
Information Technology & 4.0000 \\
Conceptual Thinking & 4.0000 \\
Identify key issues & 4.0000 \\
Psychological skills (ability & \\
understand the way people's & \\
mind works) & 4 \\
Sociological skills & \\
Simplify the information & 3.9667 \\
Legal & 3.9333 \\
Financial/Numeracy & 3.8333 \\
Commercial/business advisory & 3.8000 \\
Research Skills & 3.7333 \\
Interviewing & 3.4667 \\
Analytical proficiency & 3.2667 \\
Marketing & 2.9333 \\
\hline
\end{tabular}

It should be noted here that the skills with the high means are the most important skills required for forensic accountants, while the skills with low means but high the least important skills required to be forensic accountants.

The primary skill highlighted by the
International Journal of Accounting \& Business Finance Vol.6.No.2 December 2020 Issue. pp. 1 - 18

respondents is that deductive analysis which is the ability to take aim at financial contradictions that do not fit in the normal pattern of an assignment perform forensic accounting services in Sri Lankan context (mean value of 4.933). The second most highlighted skill is Fraud risk assessment (mean value of 4.933 which the respondents perceived is required to perform forensic accounting services in Sri Lanka). Based on the responses received, the top ten skills perceived by the respondents are fraud risk assessment, deductive analysis, diagnostic, composure, unstructured problem solving, Diagnostic, composure, solve structure problems, critical thinking, time management, think like a wrongdoer and technical accounting.

It should be further highlighted that, respondents placed a lower level of importance of the skills such as 'marketing', 'interviewing' and 'analytical proficiency'.

\subsection{Forensic accounting career path,} education and future demand in Sri Lanka

The analysis of respondents' answers given to the following questions will further elaborate the skills that are perceived to be important for a forensic accountant from the point of view of Sri Lankan accounting professionals.

\section{Other than Accounting, what under- graduate degree major do you think is most appropriate for a forensic accountant (FA)?}


Table 3

\begin{tabular}{lll}
\hline & $\begin{array}{l}\text { Frequen- } \\
\text { cy }\end{array}$ & $\begin{array}{l}\text { Per- } \\
\text { cent }\end{array}$ \\
\hline $\begin{array}{l}\text { Computer } \\
\text { Information }\end{array}$ & 29 & 96.7 \\
Systems & & \\
Economics & 1 & 3.3 \\
Total & 30 & 100.0 \\
\hline
\end{tabular}

The $96.7 \%$ of respondents think that computer information studies are more appropriate for a forensic accountant in Sri Lanka due to the fact that data mining and data analytics are more concerned with the forensic accounting these days.

\section{What is the highest level of education} that you think is needed to be a successful FA?

Table 4

\begin{tabular}{lll}
\hline & Frequency & Percent \\
\hline $\begin{array}{l}\text { undergradu- } \\
\text { ate degree }\end{array}$ & 23 & 76.7 \\
master & 7 & \\
Total & 30 & 23.3 \\
\hline
\end{tabular}

The $76.7 \%$ respondents think that undergraduate degree is enough to become successful FA while $23.3 \%$ think that to be a successful forensic accounting there should be a Master's degree.

3. What is the typical career path for a FA in your firm?
International Journal of Accounting \& Business Finance Vol.6.No.2 December 2020 Issue. pp. 1 - 18

Table 5

\begin{tabular}{lll}
\hline & Frequency & Percent \\
\hline Start as intern & 16 & 53.3 \\
Graduate & 10 & 33.3 \\
with degree & & \\
in forensic & & \\
accounting and & & \\
join firm & & 13.3 \\
$\begin{array}{l}\text { Graduate with } \\
\text { degree in }\end{array}$ & 4 & \\
accounting and & & \\
start in audit & & \\
department of & & 100.0 \\
firm & & \\
Total & 30 & \\
\hline
\end{tabular}

$53.3 \%$ suggest that start as a intern would be the most suitable career path for a forensic accountant while $33.3 \%$ believe that graduate with a degree in forensic accounting and $13.3 \%$ respond that Graduate with degree in accounting and start in audit department of the firm would be the starting point of the career.

\section{What will be the demand for forensic accountants in the future years?}

Table 6

\begin{tabular}{lll}
\hline & Frequency & Percent \\
\hline increased & 30 & 100.0 \\
decreased & 0 & 000.0 \\
\hline
\end{tabular}

$100 \%$ respondents were think that the demand for the forensic accountants in the future years will be increased. 


\section{Will there be enough forensic}

accountants available to meet the demand

in the future years?

Table 7

\begin{tabular}{lll}
\hline & Frequency & Percent \\
\hline yes & 22 & 73.3 \\
not sure & 8 & 26.7 \\
Total & 30 & 100.0 \\
\hline
\end{tabular}

The $73.3 \%$ respondents think that there will be enough forensic accountants available to meet the demand in the future years and $26.7 \%$ respondents were not sure about the demand in future years.

\subsection{Pilot survey results}

According to the Pilot survey conducted by selecting 8 qualified chartered accountants (CAs), it was revealed that forensic accountants need skills such as critical thinking and professional skepticism.

In general, they highlighted the following with regard to forensic accounting;

Forensic Accounting is looking beyond the numbers and dealing with the business reality under a particular situation.

Forensic accounting is about analysing, interpreting and summarising complex business matters

Forensic accountant is required to compile financial evidence, develop computer applications to manage the information collected and communicate their findings in the form of reports or presentation. Forensic accountants need to prepare visual aids to support trial evidence.
International Journal of Accounting \& Business Finance Vol.6.No.2 December 2020 Issue. pp. 1 - 18

Forensic accountant should explain the nature of the financial crimes to the courts and interested parties

Forensic accounting is emerging subject so that there will be lots of careers in future.

\section{Discussion and conclusion}

The skills which were found in empirical studies are summarised below;

Table 8 . Skills required by a forensic accountant

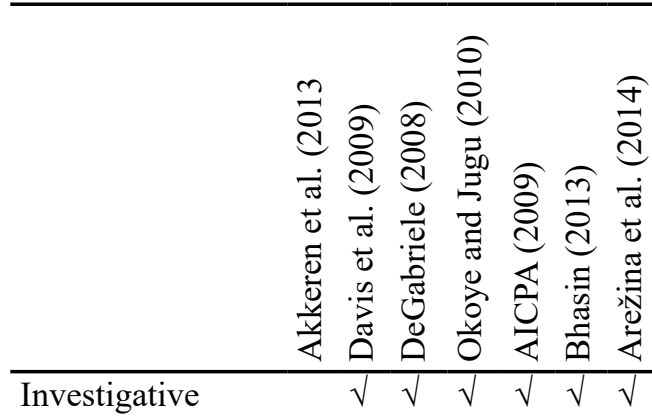

skills

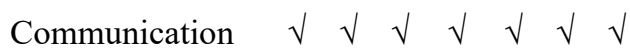

$\begin{array}{lllllllllllllll}\text { Critical Thinking } & \sqrt{ } & \sqrt{ } & \sqrt{ } & \sqrt{ } & \sqrt{ } & \sqrt{ } & \sqrt{ }\end{array}$

Deductive

analysis

Interpersonal $\quad \sqrt{ }$

skills

Technical

Accounting skills

Auditing/Industry $\sqrt{ } \sqrt{ } \quad \sqrt{ } \sqrt{ } \sqrt{ }$

experience

Diagnostic Skills $\sqrt{ }$

Technology skills $\sqrt{ }$

Conceptual

Thinking 
Legal knowledge

Interview/Investi- $\sqrt{ }$

gations

Commercial/busi- $\sqrt{ }$

ness advisory

Financial/Numer- $\sqrt{ }$

acy skills

Ability to work in $\sqrt{ }$

a team

Time manage-

ment

Fraud Risk As- $\quad \sqrt{ }$

sessment

Marketing

Unstructured

problem solving

Analytical profi-

ciency

Composure

Identify key

issues

Organize an un-

structured

Situation

Research Skills

Simplify the

information

Solve structured

problems

Think like the

wrongdoer

Understand the

goals of a case

Psychology skills

Sociology skills
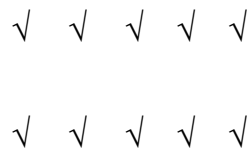

$\sqrt{ } \sqrt{ }$

$\sqrt{ } \sqrt{ }$

$\sqrt{ } \quad \sqrt{ } \quad \sqrt{ }$

$\sqrt{ } \sqrt{ }$

$\sqrt{ } \sqrt{ }$

$\sqrt{ } \sqrt{ }$

$\sqrt{ } \sqrt{ }$

$\sqrt{ } \sqrt{ } \sqrt{ }$

$\sqrt{ } \sqrt{ }$

$\sqrt{ } \sqrt{ } \sqrt{ }$

According to this study, Deductive analysis,

Fraud risk assessment, Unstructured problem solving were the top rated skills identified by the respondents which goes in line with the findings of the previous researches.

Over many generations fraud has been in existence and will be there in the future as well. In past two decades, the prominent financial scandals such as, Enron, WorldCom, Satyam have witnessed the gravity of this issue. As a result, opportunities for forensic accountants are growing at a rapid speed all around the globe. This study found out ten skills as required by a forensic accountant including fraud risk assessment, deductive analysis, diagnostic, composure, solve structured problems, critical thinking, time management while skills such as marketing, interviewing and analytical proficiency, perceived as least important. Similar findings have been reported in previous studies done by Digabriele (2010) in the USA and Okoye \& Jugu (2010) in Nigeria.

Apart from that it was found that students need information system degree to become a successful Forensic Accountant. Accounting students need to

be familiar with the role played by the information technology (IT) in the digital environment. In this context, Pearson and Singleton (2008) have rightly pointed out knowledge and application of technology is increasingly essential in effective forensic accounting, anti-fraud programs, and fraud investigations. Accounting students need to be aware of it-based schemes and have an appreciation for the need to use specialists to support the work of the accountant in auditing or investigating computer-based fraud and 
forensic accounting issues. (Many higher education accounting programs and universities are currently considering incorporating fraud examination and forensic accounting courses into their curricula.

Furthermore, the demand for forensic accountants will increase in the near future due to the number of frauds that take place in Sri Lanka. The accounting industry has gradually called for more and more forensic accountants. Literature predicts that growth of the industry, based on the amount of jobs, will reach $6.7 \%$ for the years between 2013 and 2018 (Rathnasiri and Bandara, 2018 as cited in Chiang, 2013).

\section{Limitations and future research directions of the study}

The main limitation of this study is the dearth of studies on the research topic in the Sri Lankan context. Another limitation of the study was that the sample of the research was restricted only to the accounting academics and forensic accounting practitioners. Even though there are other categories of professionals involve with the forensic accounting education and services such as, attorneys, information technology professionals, and the researcher could consider only the accounting academics and forensic accounting practitioners. Since the research is carried out based on the Sri Lankan context, the findings may not be generalised to the global context as a whole. In other words, since this research is carried out on the perspective of a developing country, it won't be much useful for the users who wanted to get an idea of a developed country.

Furthermore, the findings of this study should be interpreted subject to certain caveats.
Accordingly, it should be highlighted that, only professional accountants in public practice were considered in this study. However, the spread of big three and other practicing firms ensured that a sufficiently of views were captured. Perhaps, a future study can consider the perceptions of non-accounting professionals, such as attorneys, and identify the differences in their perceptions.

In terms of significance, this study focus on forensic accounting service as well as skills required for forensic accountant to their profession and attempts to provide information that may be useful for universities and professional bodies considering, offering a course in forensic accounting in light of most recent changes in the business environment and the accounting profession in Sri Lankan context. Since the forensic accounting is an emerging career as well as new subjects there will be high chances to students to develop their career and education by selecting the this subject area. As well as Forensic Accountants who are already in practice can developed their skills and competencies by supporting the findings of this study. Apart from the Top Four audit firms' other firms also can initiate the separate department in their firms in order to firms success.

\section{References}

Ademola, L. S. (2017). The Forensic Accountants' Skills and Ethics. Academic Journal of Economic Studies , 3(4), 77-85.

Ahadiat, N. (2010). Skills Necessary for a Successful Career in Accounting. Journal of the Department of Accounting, College of

Business Administration, 16(1), 11-25 
International Journal of Accounting \& Business Finance

Vol.6.No.2 December 2020 Issue. pp. 1 - 18

Akhidime, A.E. and Uagbale-Ekatah R.E.

Akers, M.D. and Porter, G.L. (2003). Your EQ

Skills: Got What It Takes?. Journal of Accountancy, 195(3), 65-69.

Albrecht, W.S., Albrecht, C. \& Albrecht, C.C. (2008). Current Trends in Fraud and its Detection. Information Security Journal: A Global Perspective, $17(1), 2-12$

Arewa, A. (2018). Borderless crimes and digital forensic: Nigerian perspectives. Journal of Financial Crime, 25(2), 619-631.

Arežina, N., Knežević, G., Simeunović, N. \& Vukićević, S. (2014). Forensic accountant: innate trait or acquired skill?. Finiz 2014

"Finansijsko izveštavanje u funkciji

korporativnog upravljanja. doi: 10.15308/ finiz-2014-131-134

Andon, P., Free, C., \& O’Dwyer, B. (2015). Annexing new audit spaces: challenges and adaptations. Accounting, Auditing and Accountability Journal, 28(8), 1400-1430.

Alabdullah, T. T. Y., Alfadhl, M. M. A., Yahya, S., \& Rabi, A. M. A. (2013). The Role of Forensic Accounting in Reducing Financial Corruption: A Study in Iraq. International Journal of Business and Management, 9(1)

Akkren, J.V., Buckby, S. and Tarr, J. (2016). Forensic accounting: Professional regulation of a multi-disciplinary field. Australian Business Law Review, 44, 204-2015

Akkeren, J.V., Buckby, S., and MacKenzie, K. (2013). A metamorphosis of the traditional accountant: An insight into forensic accounting services in Australia. Pacific Accounting Review, 25(2), 188-216
(2014).

The Growing Relevance of Forensic Accounting as a Tool For Combating Fraud and Corruption: Nigeria Experience. Research Journal of Finance and Accounting, 5(2), Retrieved from https://www.iiste.org/Journals/ index.php/RJFA

AICPA (2004). Forensic and Litigation Services Committee and Fraud Task Force, Forensic Services, Audits, and Corporate Governance: Bridging the Gap, Discussion Memorandum. Retrieved from www.adobe.com/prodindex/ acrobat/readstep.html

Arizona, N.K.G.S.N. (2014). Forensic accountant: innate trait or acquired skill?

Bhasin, M.L. (2007). Forensic accounting: a new paradigm for niche consulting. The Chartered Accountant, 1, 1000-1010.

Bhasin, M.L. (2013). Survey of skills required by the forensic accountants: evidence from a developing country. International Journal of Contemporary Business Studies, 4(2), 54-86.

Bhasin, M.L. (2015). Forensic accounting: perspectives and prospects. The Pakistan Accountant Journal, 1, 44-48.

Bhasin, M.L. (2016). Contribution of Forensic Accounting to Corporate Governance: An Exploratory Study of an Asian Country. International Business Management, 10 (4)

Bonner, J. (1983). Article Information, 104.

Brooks, LJ \& Labelle, R 2006, CAP forum on forensic accounting in the post-Enron world: education for investigative and forensic accounting. Canadian Accounting Perspectives, 5, 287-306. 
Carnes, K. C., \& Gierlasinski, N. J. (2001). Forensic accounting skills: Will supply finally catch up to demand?. Managerial Auditing Journal, 16(6), 378-382

Carozza, D. (2002). Accounting students must have armor of fraud examination. The White Paper: Topical Issues on White-Collar Crime, 16(1), 30-33.

Caliyurt K. T., Crowther D. (2006). The Necessity of Fraud Education for Accounting Students: A Research Study From Turkey. Social Responsibility Journal, 2 (3/4), 321-327

Cressey, D. R. (1953). Other people's money; a study of the social psychology of embezzlement. Retrieved from APA PsycInfo database.

Crumbley, D. L. (2001). Forensic Accounting: Older than you think. JTA, 2 (2) 181

Dada, S. O. (2016). Forensic Accounting Technique : A Means of Successful Eradication of Corruption Through Fraud Prevention, Bribery Prevention and Embezzlement Prevention in Nigeria. Kuwait Chapter of Arabian Journal of Business and Management Review, 4(1), 176-186.

Dada, S., Sunday, O., \& Okwu, A. (2013). Forensic Accounting a Panacea to Alleviation of Fraudulent Practices in Nigeria . International Journal of Business Management, and Economic Research, 4(5), 787-792.

Davis, C., Farrell, R., \& Ogilby, S. (2010). Characteristics and Skills of the Forensic Accountant. AICPA FVS Section, 29.

DiGabriele, J. (2010). An empirical investigation of the relevant skills of forensic accountants.
International Journal of Accounting \& Business Finance Vol.6.No.2 December 2020 Issue. pp. 1 - 18

Journal of Education for Business, 83:6, 331-338,

Retrieved from DOI: 10.3200/JOEB.83.6.331-338

DiGabriele, J.A. and Huber, D. (2013). Topics and Methods in Forensic Accounting Research. SSRN Electronic Journal, DOI: 10.2139/ssrn.2361944

Effiok, S., \& Eton, O. (2013). Ensuring quality control of forensic accounting for efficient and effective corporate management. Global Journal of Social Sciences, 12(1), 27-33.

Fullerton, R. and Durtschi, C. (2004). The Effect of Professional Skepticism on the Fraud Detection Skills of Internal Auditors. SSRN Electronic Journal, doi: 10.2139/ssrn.617062

Gaither, M. (2018). The role of forensic accounting in US. (Unpublished dissertation) University of Tennessee, Chattanooga

Grippo, F. J. \& Ibex, T. (2003). Introduction to Forensic Accounting. National Public Accountant, $4,4-8$.

Harris, C. K. \& Brown, A. M. (2000). The Qualities of a Forensic Accountant, Pennsylvania CPA Journal, 71, 2-3.

Hassan Z. And Morteza R. (2012). Accountant's Perception of Forensic Accounting (Case Study of Iran). Global Journal of Management and Business Research, 12(6)

Howieson, B. (2018). What is the 'good' forensic accountant? A virtue ethics perspective. Pacific Accounting Review, 30(2), 155-167.

Ihlas, M. and Huang, W. (2017). Forensic Accounting Education - A study of curriculums in consideration of employer expectations. LUP Student Papers BUSN79 20171 
Jensen, M.C. and Meckling, W.H. (1976). Theory of the firm: Managerial behavior, agency costs and ownership structure. Journal of Financial Economics, 3(4), 305-360

Kodongo O., Mokaleli-Mokoteli T., Maina L. (2014). Impact of Task Performance Fraud Risk Assessment on Forensic Skills and Mindsets: Experience from Nigeria. International Journal of Business and Social Science, 5(9)

Kingdom, U., \& Aduwo, O. O. (2016). The role of forensic accounting in combatting the menace of corporate failure. 4(1), 640-649.

Kramer B., Seda M., Bobashev G. (2017). Current opinions on forensic accounting education. Accounting Research Journal, 30(3), 249-264

McMullen, D., Sanchez, M. (2010). A Preliminary Investigation of the Necessary Skills, Education Requirements, and Training Requirements for Forensic Accountants. Journal of Forensic \& Investigative Accounting, 2(2), 30-48

Mark E. L. (2014). How senior managers perpetuate accounting fraud? Lessons for fraud examiners from an instructional case. Journal of Financial Crime, 21(4), 411-423

Mohamed, E. And Lashine, S. (2005). Accounting knowledge and skills and the challenges of a global business environment. Managerial Finance, 29(7), 3-16

Mohd, S. I. \& Mazni, A. (2008). An overview of forensic accounting in Malaysia. Kuala Lumpur: University of Malaysia Press Inc Melancon, B. (2002). A new accounting culture. Journal of Accountancy, 194(4), 27-30
International Journal of Accounting \& Business Finance Vol.6.No.2 December 2020 Issue. pp. 1 - 18

Messmer, M. (2004). Exploring Options in Forensic Accounting. National Public Accountant, 5, 9-20.

Nicolae, B. (2017). The Relevant Skills for Forensic Accountants. “Ovidius” University

Annals, Economic Sciences Series, 17(1), 419-423

Oladejo, M. O., \& Oluwaseun, Y. (2015). Impact of Forensic Accounting on Fraud Reduction in the Nigerian Banking Sector. International Journal of Empirical Finance, 4(4), 250-257.

Owojori, A.A and T. O. Asaolu (2009). The Role of Forensic Accounting in Solving the Vexed Problem of Corporate World. European Journal of Scientific Research, 29(2), 183-187

Okoye, E.I. \& Jugu (2010). An empirical investigation of the relevant skills of forensic accountants in Nigeria. Journal of Knowledge Management, vol. 1, no. 2

Okoye, E.I., Akenbor, C.O. (2009). A critical analysis of the fraud triangle for sustainable development in Africa. The Universiy: Advancd research journal, 1, 1-8

Pearson T. and Singleton W. (2008). Fraud and Forensic Accounting in the Digital Environment. Issues in Accounting Education, 23(4)

Perera, K.K.S. (2016). G-Key Sri Lanka's second largest financial. Retrieved from http:// www.dailymirror.lk/105292/G-Key-Sri-Lankas-second-largest-financial-.html

Prabowo, H.Y. (2014). To be corrupt or not to be corrupt: Understanding the behavioral side of corruption in Indonesia. Journal of Money Laundering Control, 17(3), 306-326

Ramaswamy V. (2005). Corporate governance 
and the forensic accountant. Journal of College Teaching and Learning. 4(9), doi:10.19030/tlc. v4i9.1545

Rathnasiri, U.A.H.A. and Bandara, R.M.S. (2018). The Forensic Accounting in Sri Lanka: Perception of Professional Accountants. Kelaniya Journal of Management, 6(2), 68-82

Rezaee, Z. (2005). Causes, consequences, and deterence of financial statement fraud. Critical Perspectives on Accounting, 16, 277-298

Rezaee, Z., Daniel Lo, Michael Ha and Suen A. (2016). Forensic Accounting Education and Practice: Insights From China. Journal of Forensic \& Investigative Accounting, 8(1), 106-119

Rezaee, Z. and Burton, E.J. (1997). Forensic accounting education: insights from academicians and certified fraud examiner practitioners. Managerial Auditing Journal, 12(9), pp. 479489. doi: 10.1108/02686909710185206

Rokosu, J. And Samuel, F. (2015). An Empirical Evaluation of Forensic Accounting Education in Nigeria Tertiary Institutions. SSRN Electronic Journal, Retrieved from https://ssrn.com/ abstract $=2661812$

Seda, M., \& Kramer, B. K. P. (2014). An Examination of the Availability and Composi tion of Forensic Accounting Education in the United States and Other Countries. Journal of Forensic and Investigative Accounting, 6(1), 1-46.

Shinde J., Poznic G., Alicia B. et al. (2011). Auditor Faux Pas and Managerial Fraud at McKesson and Robbins : A Preliminary Study Eastern Illinois University Udaysinha Shinde.
Journal of Accounting and Finance, 11(1), 40-49

Smith, G.S. and Crumbley, D.L. (2009). Defining a forensic audit. Journal of digital forensics, security and law, 4(1). Retrieved from https:// commons.erau.edu/jdfsl/vol4/iss $1 / 3$

Torpe, E.M. (2009). Careers in Forensics: Analysis, Evidence and Law. Occupational Outlook Quarterly (Spring). Retrieved from https://files.eric.ed.gov/fulltext/EJ875430.pdf

Tiwari R. K., Debnath J. (2017). Forensic accounting: a blend of knowledge. Journal of Financial Regulation and Compliance, 25(1), 73-85 Temitope, O. A. (2014). Effect of Forensic Accounting on the Financial Performance of Commercial Banks on Nigeria. Research Journal Of Finance and Accounting, 5(8), 103-110.

Thilakerathne, PMC (2010). Necessity and importance of developing forensic accounting services in Sri Lanka to mitigate corporate failures. Research Symposium, University of Kelaniya, Sri Lanka.

Tunca, C.K. and Crowther, D. (2006). The Necessity of Fraud Education for Accounting Students: A Research Study From Turkey. Social Responsibility Journal, 2(3/4), 321-327

Wolfe, D.T. and Hermanson, D.R. (2004). The Fraud Diamond: Considering the Four Elements of Fraud. CPA Journal, 74(12), 38-42.

Sirimanna B. (2009). Details of dealings at Golden Key revealed in court. Retrieved from http://www.sundaytimes.lk/090111/Financial Times/ft321.html

SEC/LEG/17/10/22, Directive issued in terms of Section 13 (c) of the SEC of Sri Lanka Act number 36 of 1987 (As amended), Retrieved 